\title{
LAS LICENCIAS URBANISTICAS EN LAS ZONAS MARITIMO-TERRESTRE, MARITIMA Y PORTUARIA
}

352.778.511.711:351.797.3

\author{
por \\ José-María Boquera Oliver
}

SUMARIO: I. LA EDIFICACION POR EL ESTADO Y SUS ORGANISMOS AUTONOMOS EN LAS ZONAS MARITIMO-TERRESTRE, MARITIMA Y PORTUARIA. DE LA EXENCION A LA IMPOSICION DE LA OBLIGACION DE OBTENER LICENCIA MUNICIPAL: 1. 1924-1961. 2. 1961-1975. 3. A PARTIR DE 1975.-II. LA JURISPRUDENCIA SOBRE EL ARTICULO 180, 1, DE LA LEY DEL SUELO.-III. EL DOMINIO PUBLICO MARITIMO: SUS ZONAS.-IV. LA PLANIFICACION DEL APROVECHAMIENTO DE LAS ZONAS MARITIMO-TERRESTRE, MARITIMA Y PORTUARIA.-V. LAS TASAS POR LICENCIAS DE EDIFICACION. VI. CONCLUSIONES.

I. LA EDIFICACION POR EL ESTADO Y SUS ORGANISMOS AUTONOMOS EN LAS ZONAS MARITIMO-TERRESTRE, MARITIMA Y PORTUARIA. DE LA EXENCION A LA IMPOSICION DE LA OBLIGACION DE OBTENER LICENCIA MUNICIPAL

1. $1924-1961$

El artículo 57 del Reglamento de Obras y Servicios municipales de 14 de julio de 1924 imponía la obligación de obtener licencia del Ayuntamiento para realizar obras en el término municipal. Pero 
"si las obras pertenecen a cualquier dependencia del Estado, deberá el Jefe de ella, antes de iniciarla, dar cuenta al Alcalde-Presidente del Ayuntamiento". Este no podía oponerse a la ejecución de la obra del Estado. Se limitaba a enterarse de su próxima ejecución. El precepto citado respondía a la convicción de que la satisfacción de los fines del Estado no podía depender de la voluntad del Municipio.

La regulación recordada hizo nacer en las autoridades y funcionarios del Estado y de sus organismos administradores de bienes de dominio público estatal, la idea de que para edificar el Estado no estaba sometido a los Municipios e incluso pensaron que los bienes estatales no formaban parte del término municipal.

En el año 1950, el Ayuntamiento de Tarragona decidió cobrar el impuesto de Usos y Consumos a los cafés y bares situados en el puerto de Tarragona. La Junta de Obras de este puerto elevó consulta al Ministerio de Obras Públicas. Este le contestó que suscitaba dos cuestiones: una práctica y otra de principio. Las resolvió diciendo «que por no afectar las exacciones en este caso a las obras, operaciones y servicios del puerto, pueden percibirse por el Ayuntamiento (respuesta a la cuestión práctica), sin que ello implique el reconocimiento de que la zona portuaria haya de considerarse en ningún caso como término municipal sujeto a la jurisdicción del Municipio" (respuesta a la cuestión de principio).

El Ministerio de la Gobernación —entonces el protector o tutor de los Municipios en la Administración central- no compartió el parecer del Ministerio de Obras Públicas. Suscitó conflicto de atribuciones y envió el expediente al Consejo de Estado. Este, en el dictamen de 10 de mayo de 1952 (1), afirmó que no era admisible entender que los puertos, por su condición de bienes de dominio nacional y uso público, no forman parte del término municipal (2), y en ellos concurren competencias estatales y municipales. El Ministerio de la Gobernación difundió el dictamen del Consejo de Estado y sus antecedentes entre los Municipios españoles (3).

La tesis de que los puertos no forman parte del término munici-

(1) Recopilación de Doctrina Legal, 1951-1952, núms. 64 y 70, págs. 48 y 52, Madrid, 1957.

(2) «Toda otra concepción - dice el Consejo de Estado- llevaría consigo el romper la continuidad administrativa del término y a concebir la acción de las demás esferas administrativas, como resultado de enclaves, en número indefinidos, existentes en aquél».

(3) Puede verse Gómez Quintana, P.: Competencias concurrentes en la zona maritimo-terrestre, Madrid, 1963. 
pal y sobre ellos no tienen ninguna competencia los Municipios, debía estar muy arraigada en el Ministerio de Obras Públicas y en los organismos portuarios, pues esgrimirla frente a la pretensión de un Ayuntamiento de cobrar el impuesto de Usos y Consumos a los establecimientos situados dentro de la zona portuaria parece reacción desproporcionada. La afirmación contraria, avalada por el Consejo de Estado, se convertirá en la premisa mayor, con frecuencia única, de los razonamientos encaminados a demostrar que la licencia municipal también era necesaria para obras y otros usos urbanísticos, en las zonas marítimo-terrestre y portuaria. Pero en los años cincuenta continuaba en vigor el Reglamento de 14 de julio de 1924, que eximía al Estado de la obligación de obtener licencia, pues no se había publicado Reglamento de Obras de la Ley de Régimen local de 1950-1955 (4).

La Ley del Suelo de 12 de mayo de 1956, en su artículo 167, estableció como regla general el criterio del Reglamento de Obras y Servicios municipales de 1924, pero permitió a los Municipios oponerse a la ejecución de las obras del Estado si estimaban que los proyectos no se acomodaban a los Planes de Ordenación Urbana.

El Estado no necesita licencia municipal para, en cualquiera de sus bienes, llevar a cabo obras de nueva planta, modificación de estructura o aspecto exterior de las existentes, la primera utilización de los edificios, la colocación de carteles de propaganda visibles desde la vía pública, etc. (art. 165 de la LS). La naturaleza jurídica del bien en donde el Estado quiere edificar no tiene ninguna trascendencia al efecto de la innecesariedad de la licencia. La exención legal de la obligación de obtener licencia era subjetiva. Pero el Estado debía poner sus proyectos de obras en conocimiento del Ayuntamiento, «el cual deberá notificarle la conformidad o disconformidad con los Planes de Ordenación. En caso de disconformidad, la ejecución del proyecto se someterá a decisión del Consejo de Ministros». El Municipio podía reaccionar, pues si el proyecto de obras no era conforme con el Plan de Ordenación y si el Ayuntamiento se oponía, el Consejo de Ministros, órgano del Estado, decidía la ejecución o no de la obra (5).

(4) Véase Clavero Arévalo, M.: «El nuevo régimen de las licencias de urbanismo", Civitas, Madrid, 1976, pág. 24.

(5) Los Planes de Ordenación Urbana, según el artículo 32, 2, de la Ley del Suelo de 1956, eran siempre disposiciones administrativas adoptadas por el Estado. Ante la posible disconformidad entre el proyecto de la obra (actuación singular) y el Plan. (disposición general), el órgano máximo de la Administración del Estado, el Consejo. de Ministros, decide sobre si debe o no ejecutarse el proyecto. La Ley del Suelo de 
En 1957, el Consejo de Estado de nuevo interviene en la cuestión que nos ocupa. Ahora más directamente. El 14 de febrero de 1957 dictaminó (6) sobre una solicitud de concesión de terrenos en la zona marítimo-terrestre (playa) para construir un hotel. Al someter la petición a información pública, el Ayuntamiento pidió se incluyera en el pliego de la concesión una cláusula sobre la observancia de las ordenanzas municipales de construcción. El Ministerio de Obras Públicas sostuvo que las ordenanzas urbanísticas municipales no rigen en la zona marítimo-terrestre. El Consejo de Estado reiteró que «el ámbito territorial de la competencia de los Ayuntamientos se extiende al término municipal, y no hay zonas exentas dentro de ese término a favor de competencias especiales. Procede, por consiguiente, incluir en el condicionado de la concesión los criterios de respeto a las ordenanzas municipales que ha propuesto el Ayuntamiento" (7).

En el supuesto de hecho del dictamen citado, el protagonista era el concesionario de una parcela de zona marítimo-terrestre para construir un hotel, no un órgano del Estado. El Consejo de Estado dice que la construcción de un hotel en la zona marítimo-terrestre debe acomodarse a las ordenanzas locales de edificación. En esta afirmación puede haber un equívoco. Después volveremos sobre ella.

El dictamen del Consejo de Estado de 14 de febrero de 1957 no se refiere de manera directa a la necesidad o no de licencia municipal para utilizar el dominio público marítimo, pero si en la construcción del hotel deben respetarse las ordenanzas municipales, corresponde al Ayuntamiento comprobar, mediante la licencia, si

1956 permitía, pues, al Consejo de Ministros la «derogación singular» de los Planes de Ordenación Urbana en favor de obras proyectadas por el Estado.

La regulación legal recordada tenía otra consecuencia. Cuando el órgano del Estado proyectaba una obra para una zona no comprendida en el Plan de Ordenación, el Ayuntamiento no podía decir que el proyecto era disconforme con el Plan. Con frecuencia las zonas portuarias y marítimas no se incluyen en los Planes urbanísticos. Si la edificación en ella se regía por una Ordenanza, la consecuencia quizá podía ser la misma.

(6) Recopilación de Doctrina Legal, 1956-1957, Madrid, 1962, núm. 90, pág. 112.

(7) El artículo 167 de la Ley del Suelo de 12 de mayo de 1956 - continúa el citado dictamen - establece esta competencia en cuanto se refiere a la materia urbanística. Después de reproducir dicho artículo, el Consejo de Estado añade: «si de lo que se trata no es, según parece, de discutir esta competencia municipal, sino de discrepar de las ordenanzas urbanas en el caso en cuestión, entonces tal discrepancia debería someterse al Consejo de Ministros, conforme al párrafo $20^{\circ}$ de dicho artículo 167 ». Este precepto se refería -como antes hemos visto- a la conformidad o disconformidad de los proyectos de obras del Estado con los Planes, no a posibles discrepancias del Estado con respecto al contenido de las Ordenanzas municipales. Por la naturaleza y finalidad de éstas son las mismas que las de los Planes. 
así ocurre. Tampoco se trataba de una licencia municipal para utilizar el dominio público marítimo, pues la construcción de un hotel no es una manera de utilizar el dominio público. Pero de este particular nos ocuparemos después.

El dictamen de 14 de febrero de 1957, aunque con poca claridad, deduce del artículo 167 de la Ley del Suelo de 1956 que el Municipio, en materia urbanística, es competente en todo su territorio, incluida la zona marítimo-terrestre, que es parte integrante del término municipal.

Los dictámenes del Consejo de Estado de 10 de mayo de 1952 y 14 de febrero de 1957 influyeron de manera decisiva y patente sobre la jurisprudencia del Tribunal Supremo (los citan las sentencias de 2 de octubre de 1967, 3 de junio de 1971 y 24 de enero de 1974). Según las sentencias de 3 de diciembre de 1982 y 23 de noviembre de 1983, fue una sentencia de 20 de mayo de 1961 -que no hemos podido encontrar - la que afirmó por primera vez que la competencia municipal resulta evidente en las zonas marítimo-terrestres y portuarias, "tanto por lo que se refiere a licencias de apertura de establecimientos industriales y mercantiles, como en cuanto interesa para la edificación o construcción...» (sentencia de 3 de diciembre de 1982).

\section{2. $1961-1975$}

Desde 1961 hasta 1975, año en el que se reforma la Ley del Suelo y se modifica su artículo 167, el Tribunal Supremo sostiene que para las obras ejecutadas por concesionario en la zona marítimoterrestre es necesaria la licencia municipal. Para llegar a esta conclusión, las repetidas decisiones judiciales forman una doctrina sobre la competencia municipal en las zonas marítimo-terrestre y portuaria que desborda el propósito para el cual nació.

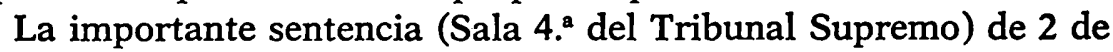
octubrc de 1967, sobre la suspensión de las obras de la central térmica que Iberduero construía en el playazo de Toretas o Erroteta de la bahía de Pasajes, afirma, y tomamos a esta sentencia como ejemplo entre unas cuantas de igual dirección:

Primero: «La zona marítimo-terrestre y portuaria es el soporte físico o espacial de diversas competencias..., que no se excluyen la una a la otra...». 
Segundo: «Las competencias de los Ministerios de Obras Públicas y Marina» en dichas zonas «se contraen a las concretamente determinadas por la Ley...».

Tercero: Para pronunciarse sobre si los Ayuntamientos pueden exigir licencia de obras en las zonas marítimo-terrestre y portuaria ha de examinarse con prioridad «si tales pertenencias del dominio público marítimo forman parte integrante del territorio municipal y, por ende, si aquellas zonas están sometidas a la jurisdicción del Ente local; la respuesta afirmativa se impone, atendiendo a la regulación de nuestro Derecho positivo en la materia...».

Cuarto: «Por lo que se refiere a las específicas competencias (municipales) en materia de urbanismo», en la zona marítimo-terrestre y portuaria, el artículo $10^{\circ}$ de la Ley de Régimen del Suelo y Ordenación Urbana, de 12 de mayo de 1956, las extiende, sin discriminación, a todo el territorio nacional, lo que aparece ya en la propia Exposición de Motivos de la Ley al decir en su epígrafe 1., párrafo $3 .^{\circ}$ : «la normativa con vigencia en todo el territorio del Estado» (8), de suerte y manera que ha de distinguirse entre la competencia que por razón de materia, con base en el principio de especialidad, viene atribuida sobre la zona marítimo-terrestre y de puertos a los órganos integrantes de la Administración central (fundamentalmente a los Ministerios de Marina y Obras Públicas) y órganos delegados de éstos, tales como las Juntas de Obras de Puertos, recayente sobre un ámbito espacial delimitado y concreto a los efectos de que dichos órganos lleven a cabo sus funciones específicas, $\mathrm{y}$, de otra parte, la jurisdicción que el Municipio, como persona jurídico-pública, ejerce ... proyectada en el ámbito espacial constituido por el llamado término municipal...

La sentencia de 2 de octubre de 1967, también dictada en relación con la «exigencia de licencia de obras cuando éstas son realizadas por un concesionario en zona marítimo-terrestre y portuaria", dice que "para que pudiera argumentarse con éxito sobre que la Administración del Estado, al otorgar la concesión, ha otorgado al propio tiempo la licencia de obras, sería preciso, en todo caso, que nos halláramos en presencia de una concesión de obras públicas strictu sensu». Una obra pública, suponemos, propia de la zona

(8) Las sentencias de 3 de junio de 1971 y 24 de enero de 1974 citan el artículo 101 de la Ley de Régimen local, en relación con los artículos 165 y 166 de la Ley del Suelo de 1956, como fundamento de la competencia municipal para el otorgamiento de licencias urbanísticas en la zona marítimo-terrestre. 
maritimo-terrestre; una obra que no la sustraiga a su finalidad (como ocurre con la construcción de un hotel o una central térmica en una playa), como sería un muro de contención, un vial, etc. Pero en estos casos, no hay concesionario de la obra, sino contratista ejecutor de la misma para el Estado.

La jurisprudencia que acabamos de recordar no se separa del criterio legal vigente en el período en el que las sentencias citadas se dictan. Los órganos del Estado no necesitan licencia de obras, cualquiera sea la clase de éstas y el lugar en donde se ejecutan, ni cuando las ejecuta el Estado directamente ni cuando lo hace por contratista interpuesto, pues el artículo 167 de la Ley del Suelo de 12 de mayo de 1956 se refería a los órganos del Estado, pero no a los concesionarios del Estado.

La sentencia de 24 de enero de 1974, Sala 4. ${ }^{\text {, }}$, en relación con la pretensión del concesionario de una parcela en la zona marítimoterrestre de que le fuera aplicado el artículo $167 \mathrm{de} \mathrm{la} \mathrm{Ley} \mathrm{del} \mathrm{Suelo,}$ decía: «A la titularidad órgano del Estado no debe dársele un contenido extensivo que abarque estos supuestos de concesión-autorización a favor de particulares, pues sólo se refiere a las obras directamente proyectadas por esos órganos, ya que aun siendo concesionario tampoco se halla investido de las facultades privilegiadas que a los órganos estatales atribuye el expresado precepto de la Ley del Suelo, toda vez que en esta clase de concesión de dominio público solamente se transfiere al particular la ocupación y el uso exclusivo de dichos bienes».

Desde 1961 a 1975, el combate jurídico alrededor de las licencias urbanísticas en las zonas marítimo-terrestre y portuaria tiene lugar entre los concesionarios de parcelas en ellas y los Ayuntamientos. Pudieron existir enfrentamientos del Estado y de las Juntas de Obras de Puertos con los Ayuntamientos, pero no los conocemos. No parece fueron significativos a efectos jurisprudenciales.

La conclusión del Tribunal Supremo fue que lo dispuesto por el artículo 167 de la Ley del Suelo de 1956 constituye un privilegio para los órganos del Estado. Los concesionarios de parcelas de dominio público marítimo no gozan de este privilegio.

Los argumentos de los concesionarios y de los Municipios y las declaraciones del Tribunal Supremo, originan lo que la sentencia de 25 de septiembre de 1981 (Sala 4.a) denomina uun cuerpo de doctrina que hace rechazable todo intento de desapoderar a los Municipios de las competencias urbanísticas en ámbitos que, como 
el de la zona marítimo-terrestre, y principalmente en las playas y las zonas portuarias, la proyección de otras potestades y los intereses implicados son propicios a pugnas competenciales, y tanto en punto a la intervención singular por la vía de la licencia..., como en punto a la ordenación urbanística...». Este cuerpo de doctrina se independiza del supuesto de hecho que lo ha hecho nacer y se generaliza.

\section{A PARTIR DE 1975}

En este ambiente, se prepara la reforma de la Ley del Suelo de 1956. En ella participan primordialmente, como es lógico, los urbanistas. Desde su perspectiva aprecian y resuelven los problemas que se han ido suscitando durante el tiempo de vigencia de dicha Ley. En el punto que ahora nos interesa, encuentran el "privilegio" del Estado de poder edificar sin licencia del Ayuntamiento, de quien se encarga de comprobar y procurar que los proyectos de obras se acomoden a los Planes de Ordenación Urbana. En nuestro tiempo, el término privilegio lleva implícita la idea de falta de justificación y provoca el deseo de eliminarlo. Es lo que hace el artículo 180, 1, del texto refundido de la Ley del Suelo de 9 de abril de 1976. Este precepto dispone que «los actos relacionados en el artículo 178 (actos de edificación y uso del suelo) que se promuevan por órganos del Estado o Entidades de Derecho público que administren bienes estatales estarán igualmente sujetos a la licencia municipal».

Unicamente, "cuando razones de urgencia o excepcional interés público lo exijan, el Ministro competente... podrá acordar la remisión al Ayuntamiento correspondiente del proyecto de que se trate, para que en el plazo de un mes notifique la conformidad o disconformidad del mismo con el planeamiento urbanístico en vigor» (9).

«En caso de disconformidad..., el Consejo de Ministros decidirá si procede ejecutar el proyecto, y en este caso ordenará la iniciación del procedimiento de modificación o revisión del planeamiento, conforme a la tramitación establecida en esta Ley» (10).

(9) El artículo $80^{\circ}$ del Reglamento de Disciplina Urbanística completa este precepto añadiendo: «entendiéndose que si en dicho plazo no se manifiesta una disconformidad expresa, se considerará que existe conformidad al proyecto por parte del Ayuntamiento. La notificación de la conformidad o el transcurso del plazo a que se refiere el número anterior habilitará, sin más, a la Administración interesada para la ejecución del proyecto de que se trate».

(10) Pueden verse Clavero Arévalo, M.: «El nuevo régimen de las licencias de urbanismo», cit.; ARGullol MURGadAs, E.: «Sobre el control urbanístico de las obras 
Hemos pasado, pues, de un extremo a otro. De los órganos del Estado «no necesitan licencia municipal para edificar o utilizar el suelo de otro modo», a «los órganos del Estado y Entidades de Derecho público necesitan licencia municipal para la edificación y uso del suelo". Pero nuestro Derecho, ni antes ni ahora, pone en relación la exigencia o no de licencia con la naturaleza jurídica de los bienes en donde las Entidades públicas quieren edificar. Tampoco tiene en cuenta la capacidad técnica de la mayor parte de los servicios municipales de urbanismo para analizar los grandes proyectos de obras preparados por el Estado. Ni los aspectos económicos del otorgamiento de licencias.

Evidentemente, como dice el Tribunal Constitucional en su sentencia número $77 / 1984$, de 3 de julio (conflicto positivo de competencia núm. 250/1982), "el concepto de dominio público sirve para calificar una categoría de bienes, pero no para aislar una porción de territorio de su entorno, y considerarlo como una zona exenta de las competencias de los diversos Entes públicos que las ostenten». Pero esa categoría de bienes, con características jurídicas propias originadas por su destino, necesariamente requiere una regulación peculiar de la edificación que en ellos se pretenda. La citada sentencia del Tribunal Constitucional concluye que «la ejecución de los planes previstos puede plantear problemas específicos debido al carácter demanial de los terrenos afectados, pero este tipo de problemas es ajeno al presente recurso».

La única excepción a la regla de la necesidad de obtener licencia municipal para la ejecución de obras estatales es la urgencia o el excepcional interés público de la obra. "Las razones de urgencia o excepcional interés público" de las obras, apreciadas por el Ministro del Departamento autor del proyecto, no hacen posible su construcción sin más, pero permiten iniciar un procedimiento en el que el Ayuntamiento puede dar o no su conformidad al proyecto (11).

de iniciativa pública», en Revista de Administración Pública, núms. 100-102, vol. III, páginas 2091 y ss.; LARUMBE BIURRUN, P. M.: "Algunas reflexiones sobre el artículo 180 de la Ley del Suelo», RAP, núms. 100-102, vol. III, págs. 2711 y ss.

Con respecto a las consecuencias de la transferencia de la competencia urbanística a las Comunidades Autónomas sobre la aplicación del artículo 180 de la Ley del Suelo, puede verse García-Trevijano Garnica, J. A.: "Aspectos sobre las transferencias de potestades a las Comunidades Autónomas; el artículo 180 de la Ley del Suelo», $R A P$, núms. 100-102, vol. II, págs. 1967 y ss.

Sobre los antecedentes del precepto puede verse LARUMBE, P. M., op. cit., páginas 2712 y ss.

(11) Se puede razonar que cuando el Consejo de Ministros impone la ejecución de un proyecto de obras en contra del planeamiento municipal, «ordenará - según el 
Si muestra su disconformidad, el Consejo de Ministros decidirá su ejecución o no ejecución.

\section{LA JURISPRUDENCIA SOBRE EL ARTICULO 180, 1, DE LA LEY DEL SUELO}

A partir de 1976, la lucha que origina la edificación en las zonas marítimo-terrestre, marítima y portuaria tiene por beligerantes, de un lado, al Estado y sus organismos autónomos, y del otro, a los Municipios. El dique de Punta Galea, el edificio para los servicios de la Junta de Obras del Puerto de Tarragona, la escollera del puerto de Cádiz, el vallado o cerramiento del puerto de Almería (12), la estación marítima de Málaga, un puerto deportivo en Alicante, son ahora las causas del combate.

Puede afirmarse, con el margen de error que toda generalización comporta, que la jurisprudencia trata de disminuir las consecuencias del artículo 180, 1, de la Ley del Suelo. En alguna ocasión incluso retoma viejos argumentos antes rechazados. La construcción del dique de Punta Galea no necesita licencia municipal, porque es muy grande y de excepcional interés público (sentencia de 3 de diciembre de 1982); el «edificio para servicios del puerto de Tarragona», construido sin licencia, se legaliza porque estaba construido en terrenos ganados al mar y no infringía ninguna norma urbanística, pues el Ayuntamiento no había aprobado normas para la ordenación de la zona de servicios del puerto (sentencia de 23 de noviembre de 1983); la escollera del puerto de Cádiz no necesita licencia porque se construye en la zona marítima, y ésta no es parte integrante del término municipal (sentencia de la Audiencia Territorial de Sevilla de 28 de diciembre de 1981).

En relación con la construcción del «dique de Puntá Galea» del denominado superpuerto de Bilbao, con un coste inicial de pesetas 3.208.343.185, la sentencia de 3 de diciembre de 1982 (Sala 3. ${ }^{\mathrm{a}}$ ) ha dicho que no se necesita licencia municipal por «la importancia de

artículo 180, 2, párrafo segundo, de la Ley del Suelo- la iniciación del procedimiento de modificación o revisión del planeamiento». En consecuencia, los Ayuntamientos sólo pueden oponerse a los proyectos de obras estatales cuando esté planificada la zona en la que las obras deben construirse. Cuando falte el Plan, o en las zonas no planificadas por el Ayuntamiento, podrá construirse sin licencia. Pero esta conclusión tiene en contra argumentos que después examinaremos.

(12) Sentencia de 23 de noviembre de 1983. 
la construcción proyectada». Resumimos drásticamente los argumentos de esta sentencia. Primero: En virtud de lo dispuesto en el número 1 del artículo 180 de la Ley del Suelo, los órganos del Estado «habrán de someterse a la previa obtención de la licencia municipal habilitante de la construcción o edificación que aquéllos pretenden realizar, tanto en las zonas marítimo-terrestres, como portuarias o en cualquier otro sitio que forma parte integrante de un término municipal, aunque... sean bienes de dominio público..., porque las zonas demaniales están integradas en un término municipal..., doctrina general determinante... de la necesidad de la previa licencia municipal para los órganos del Estado y Entidades de Derecho público que promuevan los actos relacionados en el artículo 178».

Segundo: La necesidad de la previa licencia municipal «quiebra cuando se trata de obras que por razones de urgencia o por el excepcional interés público de las mismas así lo exijan..., régimen privilegiado..., que tiene un doble fundamento, no necesariamente concurrente, como son las razones de urgencia de la obra o el excepcional interés público de la misma...».

Conclusión, la construcción del dique de Punta Galea es una obra de excepcional interés público, "no sólo porque así lo manifiesta la Administración estatal, sino porque ello... resulta patente, dado lo que aquél significa para la estructura del superpuerto de Bilbao, de gran trascendencia para las comunicaciones y transportes marítimos...» (debemos advertir que el Consejo de Ministros no hizo esta manifestación, pues no intervino en el asunto) (13), y la licencia municipal «no era... pertinente en el presente caso...».

En la sentencia que hemos resumido existe una incipiente teoría de lo que, con sus mismas palabras, puede llamarse «la intervención municipal en el campo de las grandes obras públicas de marcado interés general». Según ella, la tesis de la exigencia de licencia municipal de obras "cualquiera que sea la importancia de la construcción proyectada», "es obligado rehacerla, ya que a tenor de la misma, cualquier actuación» que pretenda algún órgano del Estado "puede quedar sin efecto si a ella se opusiera un Ayuntamiento denegando la licencia municipal para dicha obra, con primacía absoluta de las facultades municipales sobre las estatales, y ello aunque se trate del desarrollo de una gran obra pública de marcado

(13) Al Consejo de Ministros correspondía, si se hubiera opuesto el Ayuntamiento de Guecho, decidir sobre la ejecución o no de la obra; el Ayuntamiento de Guecho nunca se opuso a la construcción del dique, lo único que pretendió fue cobrar la tasa por la licencia. 
interés general..., lo que... no puede ser aceptado...», porque aunque en el urbanismo y la ordenación del territorio, las máximas competencias «corresponden a los Ayuntamientos, también es necesario admitir que hay grandes obras o construcciones de marcado interés público, cuya competencia para su realización es del Estado, según establece, por lo que al presente caso se refiere, el artículo 149, 20 , de la Constitución..., o de los Entes autonómicos, estos últimos en virtud de lo dispuesto en el número 4 del artículo 148 de la precitada Primera Ley de la Nación, competencia que no puede quedar limitada por lo que se resuelva en cuanto a dichas obras por un Ente local que en tal sentido se atribuya facultades decisorias para la ejecución de la obra en cuestión, sin perjuicio, claro está, de las que a aquél correspondan, a tenor de lo dispuesto en los números 2 y 3 del artículo 180 de la Ley del Suelo...».

La sentencia (Sala 4..$^{\text {) }}$ ) de 20 de febrero de 1984 entiende que las obras de un puerto deportivo «que contaban con la autorización estatal (por resolución del Consejo de Ministros) nacida de la concesión (art. 180, núms. 2 y 3)», impide a la autoridad local suspenderlas «al corresponder al Consejo de Ministros la competencia para apreciar las razones de interés público que abonen el proyecto de la obra pública, etc., a pesar de que exista disconformidad a la ordenación urbanística, con suspensión de la vigencia de las correspondientes determinaciones de ésta y simultánea incoación del correspondiente procedimiento de modificación o revisión, por lo que está generalmente admitido que la suspensión por el Ayuntamiento sólo puede acordarse antes de la decisión del Consejo de Ministros, puesto que a partir de ese momento el tema planteado es distinto del que ofrece una perspectiva del puro control de la observación de la Ordenación Urbanística, y por ello, el desapoderamiento municipal resulta indiscutible, como declaran en supuestos análogos las sentencias del Tribunal Supremo de 3 de diciembre de 1982 (puerto de Bilbao) y de 28 de septiembre de 1983 (obra en el aeropuerto de Valencia)».

Las sentencias citadas dan la impresión de que los Jueces comienzan a pensar que la vigente Ley del Suelo, como dicen los castizos, se ha pasado en la exigencia de licencia municipal para la realización de obras del Estado en el dominio público marítimo, y para equilibrarla vuelven a argumentos como el de los inconvenientes de la primacía absoluta de las facultades municipales sobre las estatales; los inconvenientes de la paralización de una gran obra 
pública por la oposición de un Ayuntamiento; que el mar litoral no es término municipal, tesis que reproduce la vieja y superada cuestión de si la zona marítimo-terrestre es o no parte del término municipal.

Creemos que el camino emprendido por la sentencia de 3 de diciembre de 1982 no lleva a ninguna parte. ¿Cuándo una obra comienza a dejar de tener excepcional interés público y es necesaria licencia municipal para su ejecución? La cuestión originará discusiones, exigirá dictámenes, llevará a litigios -que se resolverán definitivamente seis años después de iniciarse-, aumentará el coste de la obra, creará tensiones entre el Ayuntamiento y el Estado o los organismos autónomos estatales. Decisiones judiciales de este tipo ponen fin a un litigio de manera razonable, pero no ayudan a la disminución de los litigios.

El asunto del dique de Punta Galea era primordialmente una cuestión de dinero. La tasa por la licencia de la obra se elevaba a 103.521.322 pesetas. Posiblemente, el Tribunal Supremo pensó que no era razonable que el Estado pagara al Municipio dicha cantidad por construir un dique en el mar y dio una solución razonable con un razonamiento que nos parece débil.

El artículo 180, 1, de la Ley del Suelo contiene reglas demasiado genéricas. El problema de las licencias municipales para obras estatales no puede resolverse teniendo sólo en cuenta el sujeto titular de la obra. También deben tomarse en consideración en dónde la obra va a ejecutarse y con qué finalidad.

La distinción entre bienes de dominio público y bienes patrimoniales es demasiado importante para olvidarla en esta materia. Tampoco puede olvidarse lo que es una licencia municipal y lo que significa para una gran obra pública, ni por qué se cobra una tasa.

Pensamos, igualmente, que no es posible ni conveniente volver al criterio del artículo 57 del Reglamento de Obras y Servicios municipales de 1924 o al del artículo 167 de la Ley del Suelo de 1956. Creemos que aunque la Administración del Estado lo intentara no sería fácil que tuviera éxito (14).

(14) La Dirección General de lo Contencioso del Estado, en dictamen de 16 de octubre de 1982 (A. G.-Obras Públicas 5/82) sobre la exigibilidad de licencia municipal de obras en relación a las autopistas y carreteras construidas por el Estado, considera «absolutamente necesario modificar la normativa de la Ley del Suelo en la materia» excluyendo, simple y llanamente, las obras promovidas por entes públicos de la exigibilidad de licencia o limitando la exigencia a los supuestos en que así resulta procedente. Expone criterios para establecer excepciones a la regla general de licencia por estimar que ésta sería la vía dogmática más aceptable. 


\section{EL DOMINIO PUBLICO MARITIMO: SUS ZONAS}

Las zonas marítimo-terrestre, marítima y portuaria son de dominio público estatal (15).

La zona marítimo-terrestre es de dominio público por estar destinada al uso público (16). Se creó para que todos pudieran acercarse al mar y nada obstaculizara el disfrute público de esa línea de contacto entre la tierra y las aguas marinas (17).

La zona marítimo-terrestre, entendida geofísicamente -como lo hace la Ley de Costas (18)_, puede cambiar en virtud de fenómenos naturales. Por eso en ella -quizá también por fenómenos menos naturales- existen parcelas de propiedad privada. Parcelas que están en la zona marítimo-terrestre geofísicamente definida, pero que no son, claro está, bienes de dominio público.

En la zona marítimo-terrestre no puede construirse un hotel ni una central térmica. En puridad, el otorgamiento de parcelas para este tipo de construcciones requiere la previa desafectación de aquellas del uso público. Convertidas en un bien patrimonial del Estado es cuando podrán destinarse a un uso no público. También puede entenderse que el acto de concesión de la parcela produce su desafectación del uso público (legal o ilegalmente, esto es cuestión

(15) La Constitución, en su artículo 132, 2, así lo proclama con respecto a la zona marítimo-terrestre y el mar litoral. La portuaria también lo es, sin ninguna duda, pero por una razón diferente, y por esto y por no plantearse en ella el problema de los enclaves particulares con la misma intensidad, la Constitución no la enumera como tal. Sobre el significado de la declaración constitucional puede verse SAINZ MORENo, F.: «Dominio público estatal de las playas y zona marítimo-terrestre», $R A P$, núm. 99 , páginas 201 y ss.

(16) Artículo 3., 3, de la Ley de Costas de 26 de abril de 1969 y $1 .^{\circ}, 1$, de la Ley de Puertos. «El uso público de las playas y de la zona marítimo-terrestre... autoriza a todos a transitar por ellas, bañarse, tender redes, pescar, varar, carenar, reparar y construir embacaciones, bañar ganado y recoger conchas, plantas y mariscos y cualesquiera otros usos análogos, dentro de las prescripciones legales y reglas de policía que lo regulan» (Sentencia de 24 de enero de 1974, Sala 4.8).

(17) En la zona marítimo-terrestre se prestan servicios de salvamento y vigilancia, pero no es por esto por lo que se la considera bien de dominio público. Para la prestación de estos servicios existen servidumbres legales que soportan también los enclaves de propiedad de los particulares en la zona marítimo-terrestre (art. $4 .^{\circ}, 1$, de la Ley de Costas).

(18) La zona marítimo-terrestre «es el espacio de las costas o fronteras marítimas del territorio español - dice la Ley de Costas (art. 1., 2) - que baña el mar en su flujo y reflujo en donde sean sensibles las mareas y las mayores olas en los temporales en donde no lo sean». Esta Ley ha excluido las playas (art. $\left.1 .^{\circ}, 1\right)$ de la zona marítimo-terrestre, pero también las califica de bienes de dominio público. Igual hace el artículo 132, 2, de la Constitución. Lo que decimos en el texto sobre la zona marítimo-terrestre es aplicable a las playas. También son zona marítimo-terrestre las márgenes de los ríos hasta el sitio en que sean navegables (art. 1., 1 , de la Ley de Puertos). 
que ahora no dilucidaremos) (19). Desafectada la parcela en donde va a levantarse el hotel o la central térmica de uso público, ya no es un bien de dominio público, sino un bien patrimonial del Estado. La edificación en ella estará sujeta al régimen de la edificación en terrenos de propiedad privada.

El artículo 178, 1, punto $2 .^{\circ}$, de la Ley del Suelo dice que «cuando los actos de edificación y uso del suelo se realicen por particulares en terrenos de dominio público, se exigirá también licencia, sin perjuicio de las autorizaciones o concesiones que sea pertinente otorgar por parte del Ente titular del dominio público». La expresión «actos de edificación y uso del suelo... por particulares en terrenos de dominio público" es inexacta. Los particulares, como tales, sin ser concesionarios, no pueden edificar en estos terrenos, y si pueden hacerlo es porque estos terrenos ya no son de dominio público en razón de alguna mutación dominial.

La zona marítima también es un bien de dominio público por estar destinada al uso público (20). Discutir sobre si esta zona forma parte o no del término municipal equivale a repetir la ya superada discusión sobre si las zonas marítimo-terrestre y portuaria integran o no el territorio de los Municipios. El análisis nos llevaría al mismo resultado. Las sentencias de 30 de junio de 1979 y 28 de junio de 1980 han dicho que «todo el territorio nacional forma parte del de los Municipios, por cuanto éstos integran el Estado español». El mar litoral es territorio nacional, valga la expresión, y, por tanto,

(19) El Reglamento de Bienes de las Corporaciones locales (art. 59) admite y regula lo que denomina el «uso privativo» y el "uso anormal» del dominio público. El primero «es el constituido por la ocupación de una porción de dominio público, de modo que limite o excluya la utilización por los demás interesados». El segundo es el uso no conforme con el destino del dominio público a que afecte. Ambos requieren concesión. Pero un uso privativo y anormal de un bien afecto a un uso público separa a éste de la finalidad determinante de su naturaleza jurídica. Aquellos son conceptos artificiosos quizá para evitar las consecuencias del ir y volver de los bienes de una categoría jurídica a otra.

(20) «El mar litoral, o bien la zona marítima que ciñe las costas o fronteras de España, en toda su anchura determinada por el Derecho Internacional, con sus ensenadas, radas, bahías, puertos y demás abrigos utilizados para la pesca y navegación», «son del dominio nacional y uso público sin perjuicio de los derechos que corresponden a los particulares...» (art. 1., 2, de la Ley de Puertos).

Zona marítima y zona maritimo-terrestre son dos zonas diferentes. En alguna ocasion ha habido discusión sobre sus respectivos límites. El Tribunal Supremo ha dicho que «la zona marítimo-terrestre no es el mar propiamente dicho, sino una zona de tierra que el mar invade con la regularidad de su flujo, pues la línea litoral que la define es la bajamar». "La línea a partir de la cual se mide el mar litoral es la línea de bajamar, nunca la de pleamar» (Sentencia de 19 de junio de 1967, Sala 4."). La Ley de 4 de enero de 1977, núm. 10/77, regula la forma de fijar los límites interior y exterior del mar litoral. 
también forma parte del territorio de los Municipios (21). Pero ante casos concretos, la actitud de la jurisprudencia es otra. La sentencia (Sala 4. ${ }^{\text {a) }}$ ) de 20 de febrero de 1984 dice que «debe recalcarse que se trata de obras de construcción de un puerto sobre el mar litoral (terrenos ganados al mar), y en tal ámbito es sostenible la competencia exclusiva del Estado, tanto por razón de la situación - ubicación de la obra (sobre franja del mar territorial), como por...». Esta sentencia parece indicar que sólo cuando se ganan terrenos al mar quedan éstos comprendidos en el término municipal, "que por accesión comprende o engloba a los ganados al mar...». En esto insiste la sentencia (Sala 3. ${ }^{\mathrm{a}}$ ) de 18 de mayo de 1984, pues dice que el término municipal «que tiene límite al mar territorial..., puede experimentar incrementos por accesión natural o artificial...; se proyecta... ganar al mar territorial 24.100 metros cuadrados, con lo cual se está planeando y proyectando sobre qué terreno, prescindiendo de su naturaleza y titularidad; se integra en el ámbito territorial del Municipio...».

En los puertos existe "una zona litoral de servicio» (art. 27 de la Ley de Puertos) "para ejecutar las faenas de carga y descarga, depósito y transporte de las mercancías y circulación de las personas y vehículos», delimitada por el Ministerio de Obras Públicas. Esta zona es de dominio público por estar destinada al servicio público de transporte marítimo. Sobre las restantes zonas portuarias existe cierta indefinición legal. El artículo $1 .^{\circ}, 2 .^{\circ}$, de la Ley de Puertos considera a los puertos parte de la zona marítima y de uso público. Pero el puerto natural al que se le añaden elementos artificiales para que «exista de una manera permanente y en debida forma tráfico marítimo» (art. 13..$^{\circ}$ de la Ley de Puertos) y los puertos artificiales, son bienes de servicio público y no de uso público. En un puerto puede haber una zona que el mar bañe en su flujo y reflujo o las mayores olas en los temporales (zona marítimo-terrestre), pero su destino al servicio público del tráfico marítimo la convertirá en bien de servicio público. Su régimen jurídico será diferente del de la zona marítimo-terrestre y del de la zona marítima. Si en una zona geofísicamente marítimo-terrestre o marítima, o en zona delimitada como marítimo-terrestre o marítima, se construye un puerto, la

(21) En Francia se debatió la cuestión hasta que el Conseil d'Etat, en arrêt 20 février 1981, "Commune de Saint-Quay-Portrieux», declaró de manera expresa que los territorios de los Municipios litorales englobaban el mar territorial. Puede verse «Le prolongement en mer des territoires de communes littorales», en Actualité Juridique, Droit Administratif, 1981, núm. 9, págs. 465 y ss. 
especificidad y el mayor interés de la afectación de los bienes al servicio público que al uso público, hará que en el puerto prevalezca el régimen de bien de servicio público (zona portuaria) sobre el de bien de uso público (zona marítimo-terrestre y marítima). Esto tiene una importante consecuencia. La concesión de parcelas portuarias a particulares para la organización y prestación de servicios públicos (silos, terminal de contenedores, etc.), no cambia la condición del bien de dominio público en un bien patrimonial por continuar aquél afecto a un servicio público. El régimen de estas concesiones, a efectos del otorgamiento de licencias municipales de obras, será el mismo que las del resto de las obras en la zona portuaria.

En los puertos suele existir una zona que se utiliza para el tráfico marítimo (zona de servicio) y otra que todavía no se utiliza para este servicio y que constituye una zona que podemos calificar de reserva portuaria o "portualizable». Esta zona de reserva portuaria puede ser, desde otra perspectiva, marítimo-terrestre, marítima o un bien patrimonial del Estado. Pero el puerto es una combinación de tierra, mar, instalaciones y hombres, organizada para que, de manera permanente y adecuada, puedan atracar los buques y cargar y descargar viajeros y mercancías. Todo el puerto debería considerarse, pues, un bien de dominio público, si bien en él podrían distinguirse zonas con calificaciones diferentes en razón exclusivamente del servicio portuario y, por tanto, distintas de las actuales calificaciones de la Ley de Costas y de la actual Ley de Puertos, de zona marítimo-terrestre y zona marítima.

\section{LA PLANIFICACION DEL APROVECHAMIENTO DE LAS ZONAS MARITIMO-TERRESTRE, MARITIMA Y PORTUARIA}

La Ley sobre Juntas de Puertos y Estatutos de Autonomía, de 20 de junio de 1968 , en su artículo $3 .^{\circ}, 2$, declara que corresponde a las Juntas «la planificación... de sus futuras ampliaciones y enlace de los transportes marítimos y terrestres a través del propio puerto", y en su artículo 17, que los puertos autónomos tendrán a su cargo «la planificación de la zona de servicios y sus futuras ampliaciones».

La Ley de Costas de 26 de abril de 1969 dispone, en su artículo $1 .^{\circ}, 1$, que corresponde al Ministerio de Obras Públicas y Urba- 
nismo la «ordenación de las costas y playas», «sin perjuicio de las facultades atribuidas a los Municipios por la Ley de Régimen local». El artículo 19 de la misma Ley establece que uen las playas en que se produzca o prevea gran concurrencia humana, se formularán por el Ministerio de Obras Públicas..., un plan de ordenación general de la playa. Si el Ayuntamiento discrepara del plan propuesto, la decisión corresponderá al Consejo de Ministros» (art. 10, 8) (22).

Pero aunque no existieran dichas declaraciones y cuando no existen, al Estado corresponde la facultad de planificar la utilización del dominio público estatal en virtud de lo que la Exposición de Motivos de la Ley de la Jurisdicción Contencioso-administrativa denomina «normatividad inmanente en la naturaleza de las instituciones».

El dominio público, como le gusta decir a la jurisprudencia, es una relación de propiedad y no una relación de imperium (sentencia de 2 de octubre de 1967), pero una propiedad que, por su destino, tiene un régimen jurídico peculiar. En este régimen no es indiferente el sujeto titular del bien. Los ríos, la zona marítimoterrestre, la marítima, por ejemplo, son dominio público del Estado porque cumplen un fin general distinto del fin general que cumplen, por ejemplo, las calles, las zonas verdes, que por eso son bienes de dominio público municipal. La titularidad estatal de dichos bienes y su afectación a un uso público nacional o a un servicio público del Estado, hace nacer para éste las facultades necesarias para que el bien cumpla su destino. Facultades creadas y otorgadas por el legislador o inherentes a su naturaleza. Entre estas facultades se encuentra la de planificar la utilización del dominio público.

La Ley del Suelo de 9 de abril de 1976 concibe a los Planes Directores Territoriales de Coordinación como el medio idóneo para coordinar la planificación urbana y la que suele denominarse, de manera poco expresiva, planificación sectorial. Su Exposición de Motivos dice (IV) que "para llenar el vacío existente en el ordenamiento jurídico en orden a la conexión del planeamiento físico con el planeamiento socio-económico, se regula ex novo la figura de los Planes Directores Territoriales de Coordinación, y a los que se asig-

(22) Véanse artículo 28, 1, del Reglamento de la Ley de Costas y artículos $3 .^{\circ}, 1$, $2 .^{\circ}$ y $2,2^{\circ}$, de la Ley de 10 de marzo de 1980 . Puede verse también la sentencia de 23 de abril de 1983.

Pueden verse Vera Fernández-Sanz, A.: «La ordenación de playas y otros espacios costeros», REDA, núm. 27 (1980), págs. 577 y ss.; MENÉNDEZ ReXACH, A.: "La ordenación de playas y sus problemas jurídicos. En especial; el tema de las competencias concurrentes», en Revista de Derecho Urbanístico, núm. 76 (1982), págs. 27 y ss. 
na, como misión fundamental, la de señalar las grandes directrices que han de orientar y coordinar la ordenación urbanística del territorio dentro de las previsiones de los Planes de Desarrollo..., y establecer el marco físico en el que han de desarrollarse coordinadamente las previsiones, localizables espacialmente, de la planificación económica y social. A este respecto, se cuida la adecuada participación de organismos estatales y locales en la elaboración de los Planes Directores (23) y se atribuye su aprobación, vinculante para todas las administraciones afectadas, al Consejo de Ministros".

Todos los Planes de ordenación urbana, de obras, de industrialización, de concentración parcelaria, etc., deberán acomodarse a los Planes Directores Territoriales de Coordinación. Incluso «los Planes sectoriales que estén en desacuerdo con un Plan Director Territorial de Coordinación deberán adaptarse a las directrices contenidas en este último en el plazo señalado en el número 2 del artículo 9» (artículo 57, 2, de la Ley del Suelo).

Los Planes municipales de urbanismo se subordinan al Plan Director Territorial de Coordinación, y los Planes sectoriales también. De esta forma quedan coordinados entre sí. Pero los Planes de ordenación urbana no se subordinan a los sectoriales ni éstos a aquéllos (24). Además, como es lógico, incluso inevitable, cada Plan tiene su propio ámbito de aplicación. Un Plan de carreteras, el Plan de obras de un puerto, etc., estarán coordinados con el Plan general municipal de ordenación urbana porque aquéllos y éste se acomodaron al Plan Director Territorial de Coordinación. Pero el Plan general municipal de urbanismo no podrá planificar las carreteras, ni las obras del puerto, en el término municipal al que se aplica; ni el Plan de carreteras o el Plan de obras del puerto planificarán el desarrollo urbano en la porción del mismo territorio a la que se extienden.

La dificultad de la coordinación entre los Planes de urbanismo

(23) Artículo 30, 3, de la Ley del Suelo y artículo 107 del Reglamento de Planeamiento.

Los Municipios pueden instar la iniciación de los Planes Directores Territoriales (artículo 107, 2, del Reglamento de Planeamiento), intervenir en su elaboración (artículo 108, 1, RP), y se dará audiencia «a los Municipios a cuyo territorio afectare el Plan, que no hubieren intervenido en su redacción» para que "puedan presentar alegaciones» (art. 111, 2, RP).

(24) El artículo 76, 1, del Reglamento de Planeamiento dispone que «en desarrollo de las previsiones contenidas en los Planes Directores Territoriales de Coordinación, y sin necesidad de previa aprobación del Plan General de Ordenación, podrán formularse y aprobarse Planes especiales con las siguientes finalidades: a) Desarrollo de las infraestructuras básicas relativas a las comunicaciones terrestres, marítimas y aéreas». 
y los sectoriales se plantea con toda su crudeza cuando no existe Plan Director Territorial de Coordinación. No puede sostenerse que cuando falta el Plan Director Territorial los planes sectoriales se subordinan al Plan general municipal de ordenación urbana. No existe ningún argumento en el que asentar lo contrario. De aceptar la tesis de la subordinación de los Planes sectoriales al Plan general municipal de urbanismo dejarían de tener razón de ser los Planes. Directores Territoriales de Coordinación.

La Ley del Suelo reconoce la independencia de los denominados. Planes sectoriales con respecto a los Planes municipales de ordenación urbana. Su artículo 17 distingue entre los «Planes especiales. para la ordenación de recintos y conjuntos artísticos, protección del paisaje...» (núm. 1), y «Planes especiales para la ejecución directa de obras correspondientes a la infraestructura del territorio o a los. elementos determinantes del desarrollo urbano previstos en el número 2, párrafo $d$ ), del artículo 8 («el señalamiento y localización de las infraestructuras básicas relativas a las comunicaciones terrestres, marítimas (25) y aéreas; al abastecimiento de agua, saneamiento, suministro de energía y otras análogas»), y en el número 1 , párrafo $b$ ), del artículo 12 («los sistemas generales de comunicación y sus zonas de protección...» (núm. 2). La formación de estos Planes. "podrá realizarse por quienes tengan a su cargo la ejecución directa de las obras correspondientes a la infraestructura del territorio o a los elementos determinantes del desarrollo urbano" (26).

Tampoco puede afirmarse que sin Plan Director Territorial de Coordinación no pueden adoptarse Planes sectoriales. La Ley del Suelo, en su artículo 57, 2, antes citado, se refiere a Planes sectoriales vigentes antes de existir el Plan Director Territorial de Coordinación (27). También lo dice muy claramente el artículo 145 del Reglamento de Planeamiento, pues comienza "los Planes especiales: que se formulen sin la existencia previa de Plan Director Territorial: de Coordinación o Plan General Municipal...».

Son muy pocos los Planes Directores Territoriales de Coordinación aprobados en nuestro país, y los problemas derivados de la

(25) «La Ley del Suelo considera infraestructura básica -dice CARceller, A. («Legislación de puertos. Interés actual de este ordenamiento», $R A P$, núms. 100-102, 1983, vol. III, pág. 2297) - a la relativa a las comunicaciones marítimas, es decir, a los puertos [art. $\left.\left.80^{\circ}, 2, d\right)\right]$ ».

(26) En los Planes sectoriales para costas y puertos los Municipios son oídos en virtud de lo que disponen la Ley de Costas y la Ley de Puertos.

(27) Igualmente el artículo 13, 3, del Reglamento de Planeamiento. 
falta de coordinación entre planificación urbanística y planificación sectorial son frecuentes.

La Sala 4. ${ }^{2}$ del Tribunal Supremo, en su sentencia de 25 de septiembre de 1981, al enjuiciar la denegación por el Ministerio de la Vivienda de la aprobación del Plan Especial o Parcial de Ordenación de la Zona Portuaria de Vigo, distingue entre los intereses urbanísticos en el puerto, que son - dice- intereses municipales y de competencia del Ayuntamiento, y los intereses portuarios en el puerto, intereses sectoriales encomendados a la Administración portuaria. La distinción entre unos y otros intereses no es imposible, pero sí difícil. La citada sentencia y la sentencia apelada de la Audiencia Nacional, no aplican dicha distinción y el Tribunal Supremo exige al Ministerio de la Vivienda que elija entre una de estas dos soluciones: a) aprobar definitivamente el Plan si no aprecia deficiencias técnicas o desajustes entre Plan General y Plan Parcial u omisiones documentales, propias del Plan Parcial, o b) señalar las deficiencias técnicas o los desajustes entre el Plan General y Plan Parcial, y las subsiguientes modificaciones para que subsanadas por el Ayuntamiento, se eleve de nuevo a la aprobación definitiva, salvo que las rectificaciones sean de escasa importancia. Pero esta sentencia afirma, en uno de sus considerandos, que "la disposición final 4. ${ }^{\mathrm{a}}$ de la Ley 27/1968, y también el artículo 10, 1, de la Ley 28/1969, e interpretar, en el conjunto, la regla del artículo $3 .^{\circ}, 2$, de aquélla, concretada, en lo que ahora importa, a la atribución al Organismo Autónomo de Puertos de la 'ordenación de la zona portuaria', y la regla del artículo 10,1, de ésta, en punto a las obras de defensa, saneamiento y ordenación de las costas y playa, infiriendo que son los intereses portuarios (o de las costas y playas), esto es, los intereses sectoriales encomendados a la Administración portuaria, mas no los intereses municipales, los intereses urbanísticos, dentro del marco general de un Plan, los comprendidos en estas reglas».

La distinción entre intereses urbanísticos e intereses portuarios puede ser útil. En el puerto pueden llevarse a cabo obras que sólo tienen interés portuario (por ejemplo, el dragado de sus dársenas). Pero no imaginamos que en él puedan construirse obras de interés urbanístico sin interés portuario. Un edificio para los servicios de dirección y administración del puerto - la obra quizá menos específicamente portuaria que en el puerto puede construirse- tiene interés urbanístico y portuario (28).

(28) La sentencia de 25 de septiembre de 1981, Sala $4 .{ }^{\circ}$, dice que es de "rigurosa vigencia el fallo de este Tribunal de 3 de mayo de 1978, según el cual, ante una 
Lo habitual será que las obras en los puertos tengan interés portuario e interés urbanístico. Si los intereses portuarios son de la competencia del Ministerio de Obras Públicas y Urbanismo, de las Comunidades Autónomas en los puertos transferidos, de las Juntas de Obras de Puertos y de los Puertos Autónomos, y los intereses urbanísticos de la competencia de los Municipios, de las Comunidades Autónomas, en su caso, y del Ministerio de Obras Públicas y Urbanismo, la planificación de los puertos corresponderá a unos y otros organismos públicos. A los primeros, la planificación según los intereses portuarios, y a los segundos, la planificación según los intereses urbanísticos. La coordinación será imperiosa y también será necesario establecer quién resolverá los conflictos cuando surjan diferencias sobre los criterios de coordinación.

Existe otra distinción de los intereses con importancia para la cuestión que estudiamos. La distinción entre intereses locales o de ámbito municipal e intereses nacionales o de ámbito estatal. El artículo 214 de la Ley del Suelo dispone que «la competencia urbanística de los Ayuntamientos comprenderá todas las facultades que siendo de índole local no hubiesen sido expresamente atribuidas por la presente Ley a otros organismos». La zona marítimo-terrestre, la marítima y los puertos de interés general (arts. 132, 2, y 149, 1, 20. ${ }^{\mathrm{a}}$, de la Constitución) no son de interés local, sino nacional. Requieren, pues, el ejercicio de facultades de índole nacional que corresponden al Estado.

Los artículos 41 y 43 de la Ley del Suelo, reguladores del procedimiento de elaboración de los Planes de Ordenación Urbana, sólo por medio de la información pública procuran la coordinación de los diversos intereses, y para lograr esta finalidad la información pública es un instrumento más bien deficiente. Frecuentemente, los Ayuntamientos han obviado la dificultad de coordinar en la planificación los intereses urbanísticos y los propios del dominio público marítimo, dejando en blanco la parte de los Planes municipales correspondientes a las zonas marítimo-terrestre, marítima y portuaria.

La Orden de 20 de enero de 1971 (Boletin Oficial del Ministerio de Hacienda de 4 de febrero de 1971) ordenó a las Delegaciones de Hacienda que informaran del sometimiento a información pública de todo Plan o Proyecto que afecte a bienes demaniales al Departa.

superposición o concurso de competencias, no deben mezclarse los problemas concernientes a cada una de ellas, imperando, por tanto, en esta situación compleja el principio de especialidad». Pero la aplicación de este principio suscita diferencias y dificultades. 
mento al que éstos estuvieren afectados o al organismo autónomo que los tuviere adscritos, «recordándoles que el ejercicio de las competencias demaniales es de su incumbencia, conforme a lo dispuesto en el artículo 116 de la vigente Ley del Patrimonio del Estado (29). Por la Dirección General del Patrimonio se formulará, en su caso, la oposición a la aprobación del Plan o Proyecto, que se cursará al órgano urbanístico competente, a través de la Delegación de Hacienda, o bien, respecto de los bienes demaniales, se sugerirá dicha actuación al Departamento u organismo autónomo correspondiente».

Para el caso concreto de la zona portuaria, la Orden de 29 de marzo de 1979 del Ministerio de Obras Públicas y Urbanismo declaró que «las Juntas de Puertos, Puertos Autónomos, Comisión Administrativa del Canal Sevilla-Bonanza, tienen el carácter de organismos competentes para la redacción y tramitación de los Planes Especiales contemplados en los artículos 17, 20, 34 y 43 de la Ley sobre Régimen del Suelo y Ordenación Urbana..., ya se trate de desarrollar previsiones de un Plan Director Territorial de Coordinación, Plan General de Ordenación o Normas Complementarias y Sub. sidiarias del Planeamiento o bien, y a falta de estos instrumentos o de previsiones al respecto, para la determinación directa de las obras de infraestructura y medidas de protección que sean precisas, de acuerdo con los artículos 76 y 145 del Reglamento de Planeamiento de 23 de junio de 1978 , y siempre que las obras de infraestructura estén dentro de la competencia del organismo redactor del Plan Especial».

El artículo $20^{\circ}$ de la misma Orden dice que «en el procedimiento a seguir para la tramitación de estos Planes Especiales se tendrá en cuenta lo señalado en los artículos 41 y 43 de la Ley del Suelo...», y «la aprobación definitiva corresponderá a los órganos competentes para la aprobación de Planes Parciales si desarrollan un planeamiento previo y al Ministerio de Obras Públicas y Urbanismo en los demás casos, salvo en los territorios de las Comunidades Autónomas en que se hayan transferido las competencias urbanísticas, en las que se estará a lo dispuesto en los correspondientes Reales Decretos de Transferencias de Competencias».

Como se habrá apreciado, la Orden de 29 de marzo de 1979 con-

(29) El artículo 116 de la Ley del Patrimonio del Estado sólo dice, a los efectos que ahora interesa, que al Departamento que tenga afectado el bien le "corresponde el ejercicio de las competencias demaniales, incluida la administración y conservación de los bienes». 
tiene algún error grave y no ofrece medios para la coordinación de los intereses portuarios y los intereses urbanísticos, ni reglas -quizá porque no podía hacerlo- sobre quién debe decidir en los casos de colisión entre estas dos clases de intereses.

El Tribunal Constitucional, en sentencia número 77/1984, de 3 de julio (conflicto positivo de competencia núm. 250/1982), dice que «lo que sí parece aconsejable es que se busquen soluciones de cooperación dentro del respeto a las respectivas competencias, aunque es evidente que la decisión final corresponderá al titular de la competencia prevalente». Lo difícil será saber en cada caso cuál es la competencia prevalente. Esta sentencia del Tribunal Constitucional (FJ 6.') dice que "no puede excluirse que en un caso concreto concurran en el espacio físico de un puerto de interés general, como es el de Bilbao, el ejercicio de las competencias del Estado en materia portuaria y la del País Vasco en materia urbanística, siempre que, $y$ conviene insistir en ello, no se produzca una perturbación por ésta en aquélla». Las competencias del Estado en materia portuaria no pueden ser perturbadas por las competencias urbanísticas de la Comunidad Autónoma o de cualquier otra entidad pública (30). Por eso, el Tribunal Constitucional concluye que «esta concurrencia sólo será posible cuando el ejercicio de la competencia de la Comunidad Autónoma no se interfiera en el ejercicio de la competencia estatal ni lo perturbe».

Mientras correspondió al Estado la aprobación definitiva de los Planes urbanísticos, la defensa del interés propio del dominio público estatal no le resultó difícil, aun cuando ni él o sus organismos autónomos participasen en la elaboración de dichos Planes. Pero al ser competencia de las Comunidades Autónomas y de algunos Ayuntamientos (art. 5. ${ }^{\circ}$ del Decreto-ley 16/1981, de 16 de octubre), la aprobación definitiva de los Planes de urbanismo, el Estado ha perdido la posibilidad de defender su dominio público. Dejar la resolución de los problemas que pueden suscitarse en esta materia

(30) La sentencia del Tribunal Constitucional citada en el texto concluye que «en el presente caso el representante del Gobierno no alega en ningún momento la posibilidad de tal perturbación, y el representante del Gobierno vasco la niega reiteradamente, por lo que hay que concluir que en este caso particular no existe, y no hay obstáculo en esas circunstancias en considerar que el Gobierno vasco al realizar los planeamientos urbanísticos a que se refiere el presente conflicto no se ha excedido en el ejercicio de sus competencias». En virtud de la modificación del Plan General de Ordenación Urbana de Bilbao y su Comarca y de un Plan especial «se prevé que un ramal de la red viaria planeada penetrará en el ámbito del puerto afectando a una porción de su zona de servicios y de la zona marítimo-terrestre». 
a merced de la fuerza de los hechos puede originar, cuanto menos, frecuentes y lamentables litigios.

En las concesiones de dominio público marítimo que corresponde otorgar al Ministerio de Obras Públicas y Urbanismo es siempre preceptivo el informe favorable o, al menos, el informe de los Ayuntamientos interesados (art. 10 de la Ley de Costas). El número 8 de este precepto dispone que cuando el Ministerio no estimase aceptable el informe del Ayuntamiento decidirá el Consejo de Ministros. Esta forma de resolver el enfrentamiento de los intereses estatales y municipales no es conveniente, ni hoy sería acorde con el principio de autonomía municipal que proclama la Constitución (31).

Tenemos, pues, sin resolver una cuestión cardinal: La coordinación de los intereses inherentes al dominio público del Estado con los intereses urbanísticos que atienden primordialmente los Municipios cuando falta el Plan Director Territorial de Coordinación, lo que ocurre con mucha frecuencia. Esto puede propiciar los golpes de mano. El Estado tratará de adoptar Planes sectoriales para su dominio público antes que sean aprobados los Planes municipales de ordenación urbana para los territorios en el que aquél se encuentra (32). Los Municipios intentarán lo contrario. En este caso, incluirán o excluirán el dominio público marítimo de los Planes de ordenación urbana. La posibilidad de incluirlo la afirma la sentencia del Tribunal Constitucional, antes citada, de 3 de julio de 1984, número 77: "La atribución de una competencia sobre un ámbito físico determinado no impide necesariamente - dice- que se ejerzan otras competencias en ese espacio, como ya ha declarado este Tribunal (sentencia del TC núm. 113/1983, FJ 1.)». Pero añade que «esa concurrencia es posible cuando recayendo sobre el mismo espacio físico las competencias concurrentes tienen distinto objeto jurídico. Así, en el presente caso, la competencia exclusiva del Estado sobre puertos de interés general tiene por objeto la propia rea-

(31) Véase la sentencia del Tribunal Constitucional de 2 de febrero de 1981, FJ 3.

(32) La sentencia del Tribunal Constitucional 77/1984 dice que la Ley del Suelo «no excluye del planeamiento urbanístico las zonas portuarias, sino que busca articular la acción urbanística con la propiamente portuaria. En el caso presente no se trata, y conviene destacarlo, de un Plan especial que ordene exclusiva o principalmente el puerto, sino de un Plan general de ordenación urbana... y de un Plan especial viario que afecta incidentalmente el puerto. No se trata, por tanto, de un Plan específico para la zona del puerto, por lo que no le es de aplicación la Orden de 29 de marzo de $1979 . . . »$. Más adelante dice: «... no es necesario considerar las posibles consecuencias de la eventual redacción de un Plan sectorial referente al puerto de Bilbao, cuya existencia por ahora ni se alega ni consta». Pero puede aventurarse que la existencia de este Plan hubiera podido propiciar una solución diferente. 
lidad del puerto y la actividad relativa al mismo, pero no cualquier tipo de actividad que afecte al espacio físico que abarca un puerto. La competencia de ordenación del territorio y urbanismo tiene por objeto la actividad consistente en la delimitación de los diversos usos a que pueda destinarse el suelo o espacio físico territorial». Si los Municipios incluyen el dominio público marítimo en sus Planes de ordenación, como «el territorio de los Municipios en que existiere Plan general municipal de ordenación - dice el artículo 77 de la Ley del Suelo-, se clasificará en todos o algunos de los siguientes tipos: suelo urbano, urbanizable y no urbanizable», y habrá que aplicar esta clasificación a la zona marítimo-terrestre, a la marítima y a la portuaria.

"Constituirán el suelo urbano (art. 78 de la Ley del Suelo): a) Los terrenos a los que el Plan incluya en esa clase por contar con acceso rodado, abastecimiento de agua, evacuación de aguas y suministro de energía eléctrica, o por estar comprendidos en áreas consolidadas por la edificación, al menos, en dos terceras partes de su superficie, en la forma que aquél determine. b) Los que en ejecución del Plan lleguen a disponer de los mismos elementos de urbanización a que se refiere el párrafo anterior». Pero siempre con la finalidad de ser urbanizados y edificados en la proporción que establezca el Plan.

En la zona marítimo-terrestre, destinada al uso público, no se puede edificar. Nunca podrá ser suelo urbano, al menos en su sentido propio. Lo mismo podemos decir de la zona marítima y de la zona portuaria, en la parte de ésta ya dedicada a la carga y descarga, depósito y transporte de personas y mercancías, y a la circulación de personas y vehículos, o a la destinada en el futuro a estas mismas funciones.

Suelo urbanizable son los terrenos que el Plan general municipal declare aptos, en principio, para ser urbanizados (art. 79, 1, de la Ley del Suelo) y edificados. Las zonas que integran el dominio público marítimo, mientras conserven esta condición jurídica, no serán jamás aptas para la urbanización y edificación.

"Constituirán el suelo no urbanizable — según el artículo 80 de la Ley del Suelo-: a) Los que el Plan no incluya en alguno de los tipos de suelo a que se refieren los artículos anteriores. b) Los espacios que el Plan determine para otorgarles una especial protección a los efectos de esta Ley, en razón de su excepcional valor agrícola, forestal o ganadero; de las posibilidades de explotación de 
sus recursos naturales; de sus valores paisajísticos, históricos o culturales, o para la defensa de la fauna, la flora o el equilibrio ecológico».

Las zonas marítimo-terrestre, marítima y portuaria serán, pues, suelo no urbanizable.

En el suelo no urbanizable, «los espacios que por sus características, según el Plan general, deban ser objeto de una especial protección..., no podrán ser dedicados a utilizaciones que impliquen transformación de su destino o naturaleza o lesionen el valor específico que se quiera proteger» (art. 86, 2, de la Ley del Suelo).

Los bienes de dominio público eran no urbanizables antes de nacer la Ley del Suelo, antes de inventarse la clasificación del suelo a efectos urbanísticos (33).

La calificación del dominio público marítimo como suelo no urbanizable no añade nada al régimen de los bienes de uso público (zonas marítimo-terrestre y marítima) o de servicio público (zona portuaria).

Como las parcelas del dominio público marítimo son no urbanizables estarán sujetas —según el artículo 86, 1, de la Ley del Suelo- a las limitaciones que establece el artículo 85 de la Ley del Suelo: "1. ${ }^{a}$ Deberán respetarse las incompatibilidades de usos señalados en el Plan general. 2. ${ }^{a}$ No se podrán realizar otras construcciones que las destinadas a explotaciones agrícolas..., así como las construcciones e instalaciones vinculadas a la ejecución, entretenimiento y servicio de las obras públicas. Sin embargo, podrán autorizarse... edificaciones e instalaciones de utilidad pública o interés social que hayan de emplazarse en el medio rural, así como edificios aislados destinados a vivienda familiar en lugares en los que no exista posibilidad de formación de un núcleo de población. 3. ${ }^{a}$ Los tipos de las construcciones habrán de ser adecuados a su condición aislada, conforme a las normas que el Plan establezca, quedando

(33) El artículo $6 .^{\circ}, 1, a$ ), del Reglamento de Edificación Forzosa y Registro Municipal de Solares de 5 de marzo de 1964 dispone que no se hallan sujetas a las normas sobre edificación y enajenación forzosas «las construcciones destinadas a uso o servicio público". Sin embargo, las normas sobre planificación urbana no toman en consideración la peculiaridad de los bienes destinados a un uso o servicio público. Por eso el jurista debe obtener los criterios ordenadores de los mismos a partir de la naturaleza jurídica de esta clase de bienes. La sentencia de 25 de marzo de 1981, Sala 4. ${ }^{2}$, dice que la excepción del Reglamento de Edificación Forzosa es «una aplicación específica del privilegio de la Administración que no consiente el verse constreñida a semejante gravamen o limitación de sus bienes demaniales ni a ser tratada como un simple particular incumplidor de sus deberes de edificar». La explicación es demasiado simple y excesiva, pero muestra que el dominio público, por su naturaleza, no puede ser sometido al régimen general de la edificación en propiedades privadas. 
prohibidas las edificaciones características de las zonas urbanas». Limitaciones que, como se habrá apreciado, en su mayoría nada significan para las zonas marítimo-terrestre, marítima y portuaria.

El Plan de ordenación urbana que calificara a dichas zonas de suelo urbano o urbanizable sería contrario a la Ley del Suelo. Sería, pues, una fuente de litigios, como lo sería el planificarlas paralelamente atendiendo, de un lado, en un Plan, a su propia finalidad, y de otro lado, en otro Plan, al urbanismo. La primera planificación adoptada por el Estado, y la segunda, por los Ayuntamientos o los órganos competentes de las Comunidades Autónomas (34).

Resulta difícil, pues, admitir que el objeto jurídico de la planificación portuaria, por ejemplo, no sea el mismo que el de la planificación urbanística. En principio, la distinción es válida, pero en la práctica, dificilísima de aplicar. La coincidencia en el objeto quizá sea lo normal, y la distinción del objeto jurídico, lo excepcional. Por eso, el Tribunal Constitucional, en la sentencia repetidamente citada, hace notar lo que de peculiar tiene el caso concreto que resuelve en relación con los principios o reglas que reitera.

\section{LAS TASAS POR LICENCIAS DE EDIFICACION}

Las zonas que estudiamos pueden estar planificadas por Planes adoptados por su titular; por Planes de ordenación urbana aprobados según la Ley del Suelo y sus normas concordantes, y no estar planificadas. Ocurrirá esto último cuando las dejen fuera de su ámbito los Planes generales municipales de ordenación urbana y no las planifique el Estado de acuerdo con su destino.

No cabe duda de que las construcciones en el dominio público marítimo pueden influir en la planificación y edificación del resto del término municipal. Los viales, las redes de servicios, etc., municipales tienen que atender las necesidades de dichas construcciones, y éstas condicionan la organización de los servicios municipales.

(34) La Ley del Suelo, al regular el sistema de expropiación, dice en su artículo 136,1 , que «cuando en la superficie delimitada (por polígonos o unidades de actuación) existan bienes de dominio público y el destino de los mismos según el planeamiento sea distinto del que motivó su afectación o adscripción al uso general o a los servicios públicos, se seguirá el procedimiento previsto en la Ley de Patrimonio del Estado o, en su caso, en la Legislación de Régimen Local». Pero este precepto y las leyes a las que se remite se aplicarán sólo cuando haya que expropiar bienes de dominio público. 
Por eso, cualquiera que quiera edificar o utilizar de otro modo el suelo en un término municipal, aunque lo haga en sectores no planificados, debe solicitar licencia del Ayuntamiento correspondiente. De esta regla no puede excluirse la edificación en las zonas marítimoterrestre, marítima y portuaria. De este modo, el Ayuntamiento podrá, cuanto menos, conocer si la obra se levantará en un espacio planificado o no, y la influencia que puede tener sobre los servicios públicos municipales y sobre lo por él planificado (35).

La licencia de edificación es la autorización para edificar concedida por la Administración al administrado después de comprobar que se propone hacerlo de acuerdo con la legislación y los Planes vigentes. Por el otorgamiento de la licencia, la Administración cobra una tasa. Con el importe de la tasa, la Administración atiende el gasto que originan los servicios encargados de confrontar el proyecto de la obra con el Plan e informar sobre si la licencia debe ser concedida o denegada. La tasa, como dice la Ley General Tributaria, es un tributo cuyo hecho imponible consiste en la prestación de un servicio. La jurisprudencia ha declarado que para cobrar una tasa ha de acreditarse la prestación del servicio, y que su importe guardará proporción con la utilidad que del servicio público se obtiene, pues de lo contrario, bajo la apariencia de tasa, existirá un impuesto o tributo exigido sin contraprestación.

Cuando las zonas marítimo-terrestre, marítima y portuaria, las haya planificado el Ministerio de Obras Públicas y Urbanismo o no hayan sido incluidas en los Planes generales de ordenación urbana, los servicios técnicos municipales no podrán confrontar con la planificación local los proyectos de obras que los órganos u organismos estatales presenten a los Ayuntamientos. Además, las obras específicas de estas zonas, un faro, un dique, un muelle, una plataforma en el mar para la investigación de hidrocarburos, los silos en los puertos, etc., ni siquiera pueden compararse con las reglas de la Ley del Suelo y sus Reglamentos (36), ni tampoco con los

(35) Por lo que decimos en el texto no puede concluirse que cuando existe Plan sectorial para la zona marítimo-terrestre, marítima y portuaria, o éstas no están comprendidas en el Plan general municipal de ordenación urbana (no deben estarlo), pierde su razón de ser la solicitud de la licencia municipal. Pero también resulta indudable que a los Ayuntamientos no corresponde confrontar los proyectos de obras con los Planes sectoriales.

(36) La sentencia de 5 de octubre de 1981 declara que el ejercicio de la competencia municipal por motivos urbanísticos con respecto a un puerto «requiere el presupuesto normativo de un concreto precepto positivo..., no pudiendo, en su consecuencia, estimarse suficientemente fundada la denegación de licencia cuando ésta se apoya en simples invocaciones genéricas». "De esta forma - comenta ARGULLOL («So- 
Planes de ordenación urbana si comprenden dichas zonas. La altura de un faro no puede establecerla un Plan de urbanismo, ni la situación y condiciones de un muelle, etc. Pero sería arriesgado afirmar que así ocurrirá en todos los casos. Habrá que estudiar con detenimiento cada uno de ellos. Pero puede intuirse que cuando los Planes municipales de ordenación urbana no comprendan las zonas que estudiamos, los Ayuntamientos no compararán con nada los proyectos de obras que para construir en ellas se les presenten. En este caso, no podrán cobrar tasas, pues no prestarán ningún servicio, y la licencia será una pura formalidad. Tampoco podrán argumentar que los han comparado con la Ley del Suelo y sus Reglamentos, porque los criterios de la legislación urbanística han sido formulados pensando en la edificación que podemos llamar ordinaria. Desde éstos difícilmente podrán valorarse las obras especiales que requiere el dominio público marítimo al efecto de otorgar o denegar licencias de construcción (37).

bre el control urbanístico de las obras de iniciativa pública», cit., pág. 2700)- queda planteada la necesidad de que el planeamiento contenga suficientes determinaciones para constatar la adecuación o no de los proyectos a la ordenación», y, poco después, añade (pág. 2708) que esta remisión "comprende también las normas sustantivas de ordenación contenidas en la propia Ley del Suelo, si bien solamente la del artículo 73 , que se refiere a la adaptación de las construcciones al ambiente, puede tener utilidad en relación con las grandes obras públicas». Argullol concluye que "la precariedad - generalidad de las determinaciones del planeamiento urbanístico sobre las caracteríscas de las grandes obras públicas puede reducir en la práctica la incidencia del control urbanístico a cargo del Ayuntamiento, ya que con la imposibilidad de recurrir a criterios al margen del planeamiento, éste no contendrá los elementos suficientes para un contraste en profundidad entre el proyecto de obra pública y el Plan de ordenación».

(37) El Ayuntamiento icon qué confrontará el proyecto de un dique a construir en la zona marítimo-terrestre y marítima; el proyecto de dragado de un puerto; el proyecto de instalación de una plataforma petrolífera en el mar litoral? La Ley del Suelo $($ art. 178,2$)$ responde que con las previsiones de la misma, del Plan de ordenación urbana, el Programa de Actuación Urbanística y, en defecto de Plan, con las Normas Complementarias y Subsidiarias del Planeamiento. Estas previsiones para aquellas obras no existen. Las previsiones para la utilización del dominio público marítimo se encuentran en otras leyes. Las obras en el dominio público marítimo deben acomodarse a las Leyes de Costas, de Puertos, de Protección del dominio público marítimo y demás disposiciones que lo regulan. En principio, no corresponde a los Ayuntamientos comprobar si las obras en aquél respetan las prescripciones de estas leyes y disposiciones administrativas.

La sentencia de 24 de enero de 1974 sostiene que en el caso que resuelve «si bien la competencia para la concesión es exclusiva del Ministerio de Obras Públicas, también es necesario solicitar licencia municipal cuando la actividad de construir está sujeta a la legislación local y regulada por la Ley del Suelo». Tesis, dice la sentencia citada, que sostienen, "entre otras, las sentencias de 2 de octubre de 1967, 30 de mayo de 1969 y 17 de enero de 1972, en supuestos similares al de ahora...". Lo que demuestra, y nos parece una conclusión irreprochable, que algunas actividades de construcción no están sujetas a la legislación local, ni reguladas por la Ley del Suelo.

La sentencia de 4 de octubre de 1982, referente a la licencia municipal para la Central Nuclear de Ascó, dice que la intervención del Ayuntamiento en este caso, «por inexistencia de un específico ordenamiento urbanístico, se limitaba a adverar la 
Los Ayuntamientos deberán, según los artículos 718 y 719 de la Ley de Régimen local, adoptar ordenanzas para la exacción de las tasas por licencia de obras, y en ellas no sólo podrán, sino que deberán declarar que están exentos del pago de las mismas los proyectos de obras que por sus peculiaridades y lugar de ubicación, no pueden confrontarse con los Planes de ordenación urbana.

Cuando los Ayuntamientos no confrontan los proyectos de obras con las leyes y los planes, no deberían ni otorgar licencias. No pueden tampoco imponer condiciones a las obras construidas para servicios públicos del Estado.

La obligación de pedir licencia municipal para construir en el dominio público marítimo queda como el reconocimiento de la competencia del Municipio sobre la edificación en todo su territorio, lo que, por otra parte, nadie debe estar interesado en negar. Pero nos parece lamentable que por este motivo surjan diferencias, tensiones, litigios, que originan gastos, entre la Administración del Estado, sus organismos autónomos y las Administraciones locales.

De otro lado, los bienes de las zonas marítimo-terrestre, marítima y portuaria, y los edificios y demás instalaciones que a ellos se incorporan, en cuanto bienes de dominio público, son inembargables. Cuando los Ayuntamientos litiguen con la Administración del Estado, o con sus organismos autónomos, y consigan que los Tribunales declaren que una y otros deben obtener licencia para edificar en el dominio público y pagar la tasa correspondiente - cosa esta última que, como anteriormente hemos visto, no ocurre con demasiada frecuencia-, intentarán cobrar el importe de la tasa. La Ley General Presupuestaria de 4 de enero de 1977, artículo 44, 1, dispone que «los Tribunales, Jueces y Autoridades no podrán despachar mandamientos de ejecución, ni dictar providencias de embargo contra los derechos, fondos, valores y bienes en general de la Hacienda Pública». El artículo 2..$^{\circ}$ de la misma Ley declara que "la Hacienda Pública, a los efectos de esta Ley, está constituida por el conjunto de derechos y obligaciones de contenido económico cuya titularidad corresponde al Estado y a sus organismos autónomos". La parte más protegida de la Hacienda Pública son los bienes de dominio público (38).

concurrencia de la autorización del Ministerio de Industria para construir..., y la calificación de la Comisión Delegada de Saneamiento de la Provincial de Servicios Técnicos de Tarragona...».

(38) Los bienes del patrimonio del Estado también son inembargables (art. 18 de la Ley del Patrimonio del Estado de 15 de abril de 1964). 
No queremos decir que las deudas del Estado y de sus organismos autónomos son incobrables. Sólo decimos que si no las pagan voluntariamente son muy difíciles de cobrar (39).

Lo recordado debe tenerse en cuenta tanto al aplicar las normas vigentes, como al estudiar una regulación que elimine los inconvenientes derivados de los preceptos de la Ley del Suelo en vigor (40).

\section{CONCLUSIONES}

De conformidad con la legislación vigente, la Administración del Estado, los Puertos Autónomos, las Juntas de Obras de Puertos y demás organismos públicos deberán solicitar licencia para edificar en el dominio público marítimo (41). Los Municipios deben decla-

(39) Como se sabe, ocurre algo parecido con las deudas de las Administraciones locales. El artículo 661 de la Ley de Régimen local dispone: «1. Las deudas que contraigan las Corporaciones locales no podrán ser exigidas por el procedimiento de apremio, excepción hecha de los créditos liquidados a favor de la Hacienda pública y de los asegurados con prenda o hipoteca, los cuales se tramitarán en la forma que determina el vigente Estatuto de Recaudación... 2. Ninguna autoridad ni Tribunal podrá despachar mandamiento de ejecución ni dictar providencias de embargo contra los bienes, rentas y créditos de las Corporaciones locales. 3. El cumplimiento de las resoluciones de toda clase de autoridades y Tribunales de las que se deriven responsabilidades $\mathbf{u}$ obligaciones económicas a cargo de las Haciendas locales, cuando sean firmes, corresponderá exclusivamente a la Corporación de que se trate, la cual acordará y efectuará el pago mediante una habilitación de crédito, que se iniciará en el plazo de un mes a partir de la notificación de la sentencia o en casos extraordinarios mediante anualidades, que no podrán exceder de cinco, que se consignarán en los respectivos Presupuestos. 4. Las Corporaciones locales estarán exceptuadas de la prestación de cauciones, fianzas o depósitos ante Tribunales de cualquier jurisdicción u organismos de la Administración".

La posibilidad de embargo judicial contra la Administración se ha planteado con fundamento en los artículos 24 y 117,3 , de la Constitución. Pueden verse García DE Enterrfa-Fernández Rodríguez: Curso de Derecho Administrativo, Civitas, Madrid, 1981, vol. II, 2." ed., págs. 563 y ss.; CANo MATA, A.: «Ejecución judicial de sentencias contencioso-administrativas. El embargo a la Administración como manifestación del principio de tutela judicial efectiva», RAP, nm. 103, págs. 42 y ss., y GutrérREz DE CABIEDES, E.: «Inejecución por la Administración pública de condenas pecuniarias acordadas en sentencia firme judicial», en Libro Homenaje a Jaime Guasp, Comares, Granada, 1984, págs. 303 y ss.

(40) Se ha alegado lo dispuesto en el artículo 9.', 1, del Decreto 3250/1976, de 30 de diciembre, que pone en vigor bases de la Ley 41/1975 para conseguir la exención de las tasas por licencias de obras en los puertos, pero resulta difícil considerar a éstos "servicios públicos de comunicaciones» y a aquéllas aprovechamientos. La Dirección General de lo Contencioso del Estado, en el dictamen antes citado (véase nota 14), dice que "aún en el supuesto de las obras necesitadas de licencia, debe eximirse expresamente al Estado del pago de las tasas correspondientes».

(41) El artículo 178, 1, último punto, de la Ley del Suelo dice que «cuando los actos de edificación y uso del suelo se realizaren por particulares en terrenos de dominio público, se exigirá también licencia, sin perjuicio de las autorizaciones o concesiones que sea pertinente otorgar por parte del ente titular del dominio público». Algunos concluyen, a contrario sensu, que cuando es el Estado o algún organismo 
rar exentos del pago de la tasa por licencia de obras los proyectos que no pueden ser contrastados con la legislación urbanística y los Planes de ordenación urbana.

Cuanto antes habría que establecer un régimen propio para la edificación en las zonas marítimo-terrestre, marítima y portuaria. En estas zonas sólo caben obras para mejorar su uso público o para su utilización por medio de servicios públicos. Si mediante la concesión $\mathbf{u}$ otro título jurídico, las obras tienen otra finalidad, legal o ilegalmente, la parcela en donde se intente la edificación dejará de estar afectada a un uso o a un servicio público y ya no será bien de dominio público.

En la zona portuaria podría distinguirse entre obras portuarias sin influencia sobre la ciudad próxima o el término municipal en el que el puerto se encuentra, y obras portuarias con incidencia sobre su entorno. Los proyectos de las primeras no sería necesario enviarlos a los Ayuntamientos; los proyectos de las segundas deberían ponerse a disposición de la Administración municipal. Cuando los Ayuntamientos se opusieran a la ejecución de estas últimas, resolverían los Tribunales de Justicia.

En general, habría que sustituir la obligación de solicitar licencia por parte del Estado y de las Entidades de Derecho público, cuando deseen llevar a cabo obras en bienes de dominio público, por la de enviar los proyectos a los Ayuntamientos para que los órganos de aquéllos y éstos, siempre que los Ayuntamientos lo deseen, los examinen conjuntamente, formulen sus discrepancias, hagan sugerencias y traten de resolver aquéllas y de coordinar los propósitos de unos y otros. Las buenas relaciones de vecindad entre

autónomo del Estado el que quiere realizar actos de esta especie en bienes del dominio público estatal no necesitará licencia municipal. Pero, de una parte, y en general, las conclusiones obtenidas mediante interpretaciones a contrario sensu son siempre peligrosas y, algunas veces, ilógicas. En segundo lugar, esta conclusión obtenida a partir de una declaración del artículo 178, 1, de la Ley del Suelo, choca frontalmente con lo que de manera directa dispone el artículo 180 de la misma Ley: "Los actos relacionados en el artículo 178 que se promuevan por órganos del Estado o Entidades de Derecho público que administren bienes estatales estarán igualmente sujetos a licencia municipal». En tercer lugar, aquella interpretación lleva al resultado de que el Estado puede construir, por ejemplo, en un puerto sin licencia y el concesionario de una parcela en el mismo puerto tiene que obtener licencia para construir en ella.

Buscando argumentos para concluir que el Estado y demás Entidades públicas no necesitan licencia para construir en el dominio público, se puede razonar que el artículo 180,1 , de la Ley del Suelo dice que necesitan licencia municipal las «Entidades de Derecho público que administren bienes estatales». Administrar, en el sentido del término aplicable a las cosas, sólo se administran bienes patrimoniales. El dominio público se gestiona. Esto permitiría concluir que dichas Entidades necesitan licencia municipal para edificar en bienes patrimoniales, pero no para hacerlo en bienes de dominio público. 
Administraciones públicas son muy convenientes. El sistema actual no las favorece. Las discrepancias que no se resuelvan amistosamente sólo pueden y deben ser resueltas por la jurisdicción competente.

Debería complementarse el procedimiento existente para el otorgamiento de concesiones de parcelas en zonas de dominio público a los particulares para la prestación de servicios públicos. Convertir en trámite esencial la remisión al Ayuntamiento del expediente de la concesión para poder resolver, antes de su otorgamiento, las posibles diferencias de apreciación de todos los interesados y declarar legislativamente que cumplido dicho trámite, la concesión de dominio público hace innecesaria la licencia urbanística. 